\title{
Cultural Distance and FDI: China Africa Perspective
}

\author{
0'scawn Gagne \\ University of International Business and Economics, Beijing, China \\ Email: wwgagne@yahoo.fr
}

How to cite this paper: Gagne, O. (2018) Cultural Distance and FDI: China Africa Perspective. Open Journal of Business and Management, 6, 382-399.

https://doi.org/10.4236/ojbm.2018.62028

Received: March 6, 2018

Accepted: April 24, 2018

Published: April 27, 2018

Copyright (C) 2018 by author and Scientific Research Publishing Inc. This work is licensed under the Creative Commons Attribution International License (CC BY 4.0).

http://creativecommons.org/licenses/by/4.0/

\begin{abstract}
Since the establishment of the Forum on China-Africa Cooperation back in 2000, Chinese investment in Africa rapidly increased. Almost two decades later, the economic partnership between China and African countries is facing both opportunities and challenges. This paper studies the impact of cultural distance on FDI, in the specific context of China-Africa cooperation. We employ generalized least squares regression analyses to estimate the impact of cultural distance on Chinese Outward FDI in 40 African countries from 2003 to 2015. Our results indicate that cultural distance has a significant negative impact on Chinese investment in Africa. Furthermore, distance in two of the four cultural dimensions has a bigger impact on FDI: Masculinity/Femininity and Uncertainty avoidance. We conclude that from China-Africa perspective, cultural distance creates additional barriers to Chinese investment.
\end{abstract}

\section{Keywords}

Cultural Distance, FDI, China-Africa

\section{Introduction}

The rise of China as a new power, bringing hope to other developing countries on one hand, and challenging the position of developed countries on the other, is probably one of the underlying reasons why there are tensions around the world. In this challenging international environment, the economic cooperation between China and African countries is facing multiple challenges and opportunities at the same time.

Since the establishment of the Forum on China-Africa Cooperation back in 2000, the cooperation between China and African countries has reached a higher standard. As a key area of this cooperation, Chinese investment in Africa rapidly increased. According to the Chinese Ministry of Commerce, China's foreign di- 
rect investment in Africa has experienced a 37\% average annual growth from 2000 to 2015. Chinese investment stock has even exceeded 30 billion US dollars, 60 times that of $2000^{1}$.

The sudden increase of the investment volume between China and African countries has prompted many economists to wonder if traditional investment determinants also apply to China and African countries [1]. Distance is among the key determinants of economic exchange between countries. Along with geographic distance, cultural distance defined as "the degree to which shared norms and values differ from one country to another" [2], has also received a lot of attention in the literature. Cultural distance can affect bilateral preferences, bilateral trust, and transaction costs between two partner countries. Cultural distance also often means different management practices from one country to another. For all these reasons, cultural distance is believed to have a significant impact on foreign investment.

However, although China and African countries invest a lot of resources to reduce the "cultural gap" between China and Africa, only a few studies have shed light on the impact of cultural distance on Chinese investment in Africa. Overall, the literature on the impact of cultural distance on FDI is mostly directed towards the economic relationship between developed countries and other developed countries, or towards the relationship between developed and developing countries. The first contribution of this study is to raise awareness on the fact that that cultural differences also exist between developing countries. Our study takes a specific approach by explaining the different mechanisms through which cultural distance may influence Chinese investment in African countries. We believe that a good understanding of the impact of cultural distance is one of the key factors that will determine the future of the economic relationship between China and African countries. The second and most important contribution of this paper is the attempt to study empirically the impact of cultural distance on Chinese investment in Africa. Despite the fact that several cultural conflicts happen every year involving Chinese companies in Africa, few studies have so far been able to investigate empirically the impact of cultural distance on Chinese investment in African countries.

To fill in this gap in the literature, we employ general least squares regression analyses to test our hypothesis regarding the impact of cultural distance and on Chinese Outward FDI in 40 African countries from 2003 to 2015. Our results indicate that cultural distance has a significant negative impact on Chinese investment in Africa. Furthermore, distance in two of the four cultural dimensions has a bigger impact on FDI: Masculinity/Femininity and Uncertainty avoidance. We conclude that from China-Africa perspective, cultural distance creates additional barriers to Chinese investment.

Of course, this study has a few limitations, the most important being the

${ }^{1}$ Press conference of the Ministry of Commerce of the People's Republic of China (December $2^{\text {nd }}$ 2015) http://www.mofcom.gov.cn/article/ae/slfw/201512/20151201199367.shtml 
availability and the reliability of the data. Not only is there limited data on African countries' cultural dimensions, the official data on Chinese FDI in Africa that we used is also scarce and often considered underestimated. These limitations affect the robustness of our results and call for more efforts to study empirically the impact of cultural distance on Chinese investment in Africa.

We organize the remainder of this study in the following way: In Chapter 2, we give an overview of Chinese investments in African countries. In Chapter 3, we review the related literature on our topic and explain how this study fits in. In Chapter 4, we present the data and the model specifications. The regression results are discussed in Chapter 5. Chapter 6 concludes the study.

\section{Overview of Chinese Investment in Africa}

The $21^{\text {st }}$ century has witnessed a significant increase of the Chinese Foreign Direct Investment (FDI) volume into Africa. African countries, already attractive for their abundant resources and their great market potential, have also improved their economic and political environment, making them an ideal destination for Chinese Companies that are wishing to "go global".

Given the growing interest of Chinese companies for the African market, the impact of Chinese FDI on African countries, whether positive or negative, has become a very hot topic in the literature. On one hand, many scholars question the true motives and the real impact the Chinese investment activities in Arica. Protection of the environment and quality jobs creation are among the top concerns raised about Chinese investments. On the other hand, many also point out the undisputable positive boost brought by Chinese investments to African countries economies.

This debate put aside, the story of Chinese FDI in Sub Saharan Africa remains widely unknown [3]. In this section, we give a clear picture of Chinese FDI in Sub-Saharan Africa. We review the history, the main actors, the distribution, and finally the current state and the future of Chinese FDI in Africa.

\subsection{The History of Chinese Investment in Africa}

Unlike developed countries, Chinese did not rapidly engage big scale investment in Africa. It was only after Chinese companies acquired sufficient international experience, and after African countries economic and political situation improved, that Chinese investment in Africa started taking off. Despite the slow beginning, Africa is rapidly becoming an important destination for China's outward direct investment.

From an historical perspective, Chinese investment in Africa experienced three main phases:

The first phase: 1960-1980

Following the Bandung Conference in 1955, China progressively established diplomatic ties with the newly born African countries and gave its support through aid and military assistance. In return, China obtained political support 
from African countries. During that period, Sino-African relations mostly remained on the political level.

The second phase: $1980-2000$

After adopting the open-door policy, the relationship between China and African countries started shifting to a new level with more emphasis on economic co-operation and peaceful coexistence. During that period, state-owned enterprises (SOEs) remained the main investment actors on the African continent because private companies were only allowed to invest abroad after the 2000 reform [4]. SOEs investing in Africa include Central Government companies and Provincial governments companies. While provincially-owned companies tend to rely on the diaspora living in African countries, companies owned by the Central Government rely on state-to-state agreements to conduct their business. In the early 1990s, large Chinese state-owned enterprises lead numerous resource extracting, infrastructure, and public building projects in Sub-Saharan Africa (roads, schools, highways, dams, bridges, office buildings). Most of these projects were funded by the Chinese Government. Chinese investment in African was in part motivated by the increasing demand in resources needed to fuel China's economic growth.

The third phase: 2000 -

Following the launching of the "Go out" strategic call, the creation of the Forum for China-Africa Cooperation (FOCAC), and later on the launching of the One Belt One Road Initiative, Chinese small and medium private companies emerged as the new driving force of Chinese investment in Africa. The outward investment liberalization process had successfully reduced the administrative and fiscal obstacles to international investment, allowing private companies to play a bigger role. Key policy incentives, such as special economic zones and easy access to loans, were offered by the Chinese Government to encourage Chinese private companies to invest in Africa, what many companies were already willing to do because of the saturated domestic market. These private Chinese companies include small, medium, and a few large companies. There is also a great deal of micro enterprises [3]. Small and medium companies are mostly involved in communications, wholesale trading, and manufacturing. As far as micro enterprises, they tend to invest in small-scale manufacturing or retail.

On the other side of the "win-win" cooperation, many African countries still in their development stage needed infrastructures and manufacturing facilities to achieve their development goals. Chinese FDI not only provided an answer to this need, it also created many job opportunities. It is also worth mentioning that Western countries played an important role in paving the way for Chinese companies to invest in Africa by enforcing liberal investment policies in Africa [3].

As we can see from this brief historical summary of Chinese investment in Africa, Chinese FDI has greatly diversified over the years. In many African countries, China has even become the leading investor in almost all the sectors. 
Also, from the initial political ties to the more recent economic co-operation, Chinese investment in Africa has almost always been a win-win cooperation situation. Going further, the next section will give us more details about the current situation and the future perspective of Chinese investment in Africa.

\subsection{The Current State and the future of Chinese Investment in Africa}

The strong interest in Chinese investment in Africa is very much related to the rise of China as a global power able to challenge the leading position of the US and European companies on the African Continent. Indeed, Chinese FDI in African countries has been growing at a very high speed, especially since year 2000 (see Figure 1). However, as impressive as this may look, Chinese FDI still represents a small share of FDI flows into Africa, and a small share of Chinese Outward FDI flows as well. In 2016, Chinese FDI flows in Africa have reached 2.4 billion dollars, which only represents a little more than $1 \%$ of Chinese total FDI flows in that year².

In terms of Chinese investment distribution in Africa, the top three industries in Africa remain the construction industry, the mining industry, and the manufacturing industry. These three industries represent altogether almost $70 \%$ of Chinese FDI stock on the African continent. However, next to these traditional industries that continue to develop, Chinese FDI in Africa has begun to diversify. Chinese companies now invest in new industries such as telecommunications, tourism, home appliances etc. ${ }^{3}$

By the end of 2016, there were 3254 Chinese companies registered in Africa, a little less than $9 \%$ of the total number of Chinese companies registered abroad. The top destinations of Chinese companies in Africa are Zambia, Nigeria, Ethiopia, South Africa, Tanzania, Kenya, Ghana, and Angola. As mentioned before, private companies have taken the leading role in China's outward investment, both globally and in Africa. Statistics show that from 2006 to 2016, the share of Chinese state companies involved in foreign direct investment was reduced from $81 \%$ to $54.3 \%$. Also, Africa has become the top destination for Chinese small and medium enterprises. $32 \%$ of these companies choose to invest in Africa, while only $20 \%$ prefer South-Eastern Asia ${ }^{4}$.

There are many reasons to believe that Chinese companies will continue to invest in Africa.

First, from China's own perspective, many Chinese companies like TCL or HAIER need to find new markets to absorb their production surplus, not to mention the growing competition on their local market. Africa represents the best market for these companies, not only because the market potential is huge, but also because the industrialization level is still low, causing the prices of manufactured products to be high. Also, China still needs to acquire strategic assets

\footnotetext{
${ }^{2} 2016$ statistical bulletin of China's Outward Foreign Investment.

${ }^{3} 2016$ statistical bulletin of China's Outward Foreign Investment.

${ }^{4} 2016$ statistical bulletin of China's Outward Foreign Investment.
} 


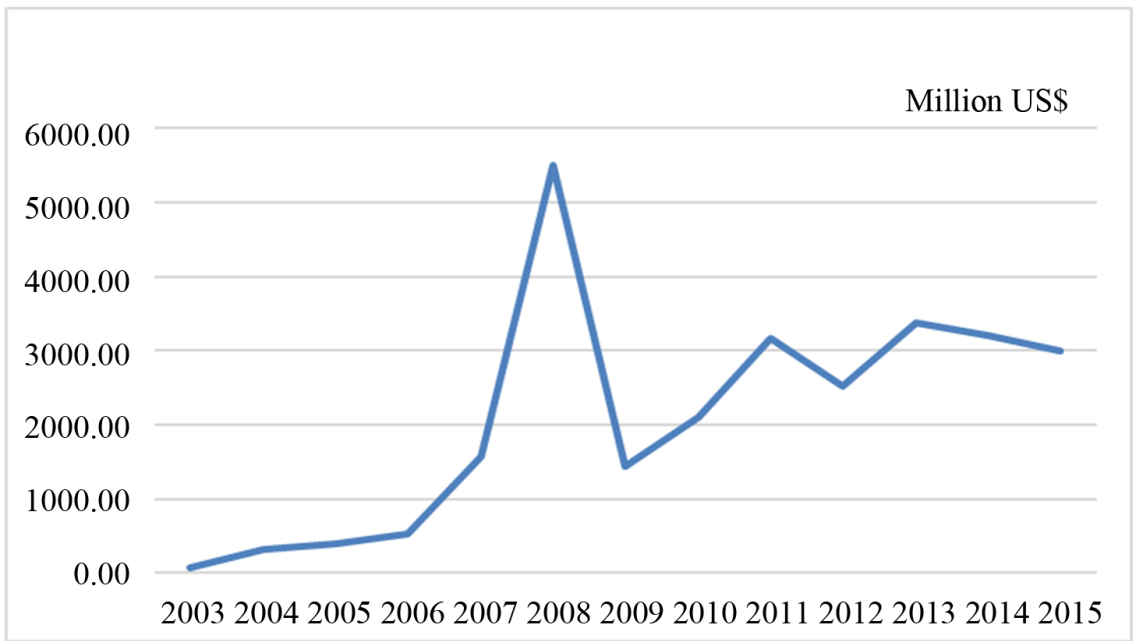

Figure 1. Chinese FDI flows to African countries. Source: UNCTAD/Chinese statistical yearbook.

and resources in order to fuel its development. And multinationals like SINOPEC are key instruments to acquire these assets from Africa, a continent rich in resources. Finally, the most important guarantee that Chinese companies will continue to invest in Africa is the strong support given by the Government to "Go out", and the deepening of the political ties between China and African countries through platforms like FOCAC.

On the other hand, we believe that African countries will continue to welcome Chinese investment. Not only do African countries expect to learn from China's positive experience, they also expect China to fulfill its « international responsibility» towards other developing countries through financial assistance and technological expertise, in order to achieve their own industrialization and urbanization.

As more and more Chinese companies turn towards the African continent, as investment sectors and projects keep diversifying, one can expect Chinese FDI to increase its influence in Africa. For that to happen, China and African countries will have to solve many issues still standing on the way:

- Most African countries are still considered highly risky. Frequent ethnic conflicts and political turmoil threaten the safety of Chinese individuals and properties. Most African countries are yet to provide a safe business environment for foreign investors, due to the instability of economic policies.

- Chinese multinationals still suffer a bad reputation, justified or not. For example, Chinese investment in Africa is often perceived to follow the state-driven strategy of giving infrastructure and taking natural resources. Some critics also accuse China of passively tolerating human right violations policy and authoritarian regimes in exchange of economic benefits. Last but not least, Chinese companies are also criticized for potentially crowding out the African manufacturing industry, providing poor-quality jobs, and polluting the environment [5]. 
- Financing the projects is one of the key problems in China-Africa investment partnership. Chinese companies are often required to invest in their projects and in basic infrastructures as well, which becomes a real burden. Many African countries still lack basic infrastructures needed for production like electricity, water and transportation.

- Chinese companies, compared with Western companies, have to face more institutional barriers, both for formal and informal ones. As a result, it is difficult even for the top Chinese companies to compete with Western companies that beneficiate from the close relationship maintained between their country and their former colonies.

Our study looks at the impact of one of the informal institutional barriers, cultural distance, on Chinese investment in Africa. The next chapter discusses the literature's findings on this topic.

\section{Literature Review}

Culture matters! This is the general conclusion on the relationship between culture and economics. However, after all these years of research, not only is it still difficult to define what culture is, it is also difficult to explain what kind of impact cultural differences have on foreign investment.

Firms engage in FDI either to seek efficiency, new resources, new markets, or strategic assets [6]. Along with these main motives, several other factors determine the FDI location choice, including economic, political, geographic, and cultural factors.

Cultural distance is often considered as part of informal institutions. For the following reasons, most studies generally agree on the fact that Outward FDI is negatively affected by cultural differences. First, cultural distance raises uncertainty about the host country's cultural environment, increasing the cost of acquiring, interpreting information, and the risk of misinterpretation as well. In this context where international managers may find it difficult to perceive cultural barriers and make the appropriate decisions, the host country's attractiveness may be significantly affected [7] [8]. Secondly, foreign investment requires multinationals to interact with host countries' stakeholders. However, cultural distance often means differences in business and management practices. In this context, getting familiar with local laws is far from being enough. Multinationals will also have to adjust to unwritten, unspoken rules of the game as well, culture so to speak [9]. As a result, multinationals cannot easily transfer home country practices to the host country, which increases the cost of doing international business [10] [11].

On the other hand, several studies argue that cultural distance has a positive impact on FDI: First, cultural distance can increase the perceived barriers and discourage bilateral trade, leading multinationals to increase FDI [12]. Also, if cultural distance may represent a liability on the short term, it can become a serious opportunity on the long term, because multinationals that invest in cultu- 
rally distant countries will develop ability to adapt and acquire knowledge [13].

In line with the theoretical findings, the empirical literature on the relationship between cultural distance and FDI has also reached mixed results:

- Loree and Guisinger [14] look at the impact of policy and non-policy determinants on the location of US equity FDI. They find that cultural distance, measured by the Hofstede index, has a negative impact on FDI location of US firms, but also that this impact is diminishing over time. They explain that the more firms and managers gain international experience and go through trainings, the more skills they acquire to break down the cultural distance barrier.

- Sethi et al. [15] analyze the changing trends in the flow and determinants of US MNEs' FDI. They argue that changes in preferences and tastes of consumers make them converge to a global norm, reducing progressively the impact of cultural distance. The empirical results confirm the intuition that US MNEs have progressively lost consideration for cultural proximity as a key determinant of FDI location choice.

- Tang [16] takes a particular approach by testing empirically the impact of each one of Hofstede's cultural dimensions on FDI. She also uses GLOBE cultural scores to check for robustness. The results first show that difference in "Individualism" between two countries has a positive impact on FDI, while difference in "Power Distance" negatively affects FDI. One of the key findings of this paper is the fact that investment in a culturally distant country is not necessarily a bad move for Multinationals.

- Siegel et al. [9] focus on "Egalitarianism", one of Schwartz's cultural orientations, to investigate the impact on cultural distance on FDI location. Using a gravity model with panel data from 1970 to 2004, they find that egalitarianism distance has a negative, statistically significant impact on FDI location choice.

Chinese FDI remains even to this day, a very hot study topic in the literature. What triggers so much interest in China's international economic activity is on one hand, the fact that the "Kingdom of the Middle" that was once a top destination for the world's FDI, has progressively turned into a major source country of FDI in the world. On the other hand, what also makes China a very interesting study topic is the fact the determinants of China's trade and investment sometimes seem to differ from the general theory, which mostly apply to developed countries. For example, unlike Western countries, China does not seem to avoid countries that are considered risky or politically unstable (like many African countries), nor does China seem to request institutional reforms from host countries.

Several studies show that the main determinants of China's outward FDI are the host country's market size, economic growth, degree of openness, endowment of resources, and the imports volume form China [17]. Cultural Distance has also been tested as one of the determinants of China's Outward FDI. Chinese 
firms are expected to gradually increase their international involvement, starting with countries culturally close to home where language and business practices are almost the same. In addition, scholars believe that the ethnic Chinese population living in the host country can explain the patterns of Chinese FDI. Overseas Chinese are well known for being among the most active diaspora in terms of promoting direct investment. Not only can this Chinese diaspora help Chinese firms identify business opportunities, it can also help them reduce transaction costs and business risks even in highly uncertain environments [18] [19].

The empirical literature gives us valuable information about the impact of cultural distance on Chinese FDI:

- Buckley et al. [4] use official data from 1984 to 2001 to investigate the determinants of Chinese ODI. They find a significant positive relationship between cultural proximity, measured by the proportion of ethnic Chinese in the host population, and Chinese ODI. In other words, psychic (or cultural) distance between China and the host country, meaning the absence of a Chinese Diaspora network, does not encourage Chinese firms to make investments.

- Quer et al. [20] study the impact of political risk and cultural distance on the FDI location choice of large Chinese companies. They used data from Outward FDI investment made from 2005 to 2009 by 35 large mainland Chinese companies listed on the Fortune Global 500. They used two different measures for cultural distance: One is the Kogut and Singh index. The other is the percentage of ethnic Chinese in the host population based on the Ohio University data. This dummy variable takes value 1 when this percentage is higher than $1 \%$ and 0 otherwise. Although cultural distance, as measured by the Kogut index, does not have a significant impact on Chinese FDI, Chinese companies' investment is found to be boosted by the presence of overseas Chinese in the host country.

- Qi et al. [8] employ a panel data set of Chinese ODI in 40 host countries from 2003 to 2010. Their analysis shows that Chinese OFDI mostly flows to countries with greater cultural similarity to the Chinese culture. In other words, low cultural distance promotes Chinese FDI. However, they also find that high cultural distance does not necessarily discourage Chinese FDI.

All these studies on Chinese FDI seem to give us confirmation that Chinese companies process of internationalization is indeed very special. Cultural distance, if measured by traditional cultural dimensions, does not seem to affect Chinese Outward FDI at least as much as it does for Western companies. However, the presence of ethnic Chinese in the host country seems to be a very decisive factor influencing Chinese Outward FDI.

Despite the fact that cultural distance receives more and more attention in the literature, few studies focus specifically on the impact on cultural distance on the economic relationship between developing countries. Moreover, fewer studies have focused on the impact of cultural distance on Chinese investment in Africa. 
This is rather surprising, given the fact that Chinese investment in Africa is such a hot research topic. Hence, it would be interesting topic to find out whether cultural distance is among the determinants of Chinese investment not in the whole world, but in the specific context of Africa. Our study fills up the gap in the literature by testing empirically the impact of cultural distance on Chinese investment in Africa. We believe that a good understanding of the impact of cultural distance is one of the key factors that will determine the future of the economic relationship between China and African countries.

\section{Model Specification and Data}

\subsection{Hypothesis}

The impact of cultural distance on FDI mainly depends on the main motivation of the Multinational Company. Some companies seem to avoid countries that are culturally distant because this new environment often means additional costs and different management practices. This is the traditional view on the impact of cultural distance on FDI. Other companies however, are not reluctant to invest in culturally distant countries because these countries offer long term opportunities such as markets, resources, or assets. Interestingly, this second behavior is considered by many as Chinese companies' behavior. Hence, our main hypothesis regarding the impact of cultural distance on FDI is the following: Cultural distance has a negative but not significant impact on Chinese FDI in African countries.

\subsection{Data Description}

\subsubsection{Dependent Variable}

The data for our dependent variable, Chinese Outbound FDI, is taken from the statistical bulletins published by China's Ministry of Commerce (MOFCOM), and the UNCTAD Bilateral FDI Statistics. This study includes Chinese outward FDI into 40 African countries from 2003 to 2015.

\subsubsection{Independent Variables}

To measure cultural distance, we use the Kogut and Singh index [10]. This index measures cultural distance based on four dimensions of national culture (Power distance; Individualism vs collectivism; Masculinity vs Femininity; Uncertainty avoidance) derived from Hofstede's work ${ }^{6}$. The data is available for a total of 18 African countries. We extend scores to some countries that we believe are culturally close, to get a total of 40 African countries in our dataset. The African countries selected and their cultural distance with China are detailed in the Appendix 1. We expect to find a negative but not significant relationship between Chinese OFDI and cultural distance.

Beside our main independent variable, we also add variables that reflect the

${ }^{5} \mathrm{We}$ used the data collected and published by the China Africa Research Initiative https://www.sais-cari.org/data/

${ }^{6} \mathrm{https} / /$ www.hofstede-insights.com/product/compare-countries/ 
main determinants (motives) of Outbound FDI derived from theory of firm internationalization.

First, we consider market seeking as being a key motive for Chinese Outward FDI. We expect Chinese Outward FDI to be positively associated with the African (host) country's market size because it offers more opportunities to generate profit. Chakrabarti [21] points out that "a large market is necessary for efficient utilization of resources and exploitation of economies of scale". Thus, we use both GDP and GDP per capita to control for market seeking FDI. The data is taken from the World Bank Development Indicators database.

Resource-seeking FDI is the second Outbound FDI motive we include in our model. Many studies argue that Multinationals Outbound investment has been one of the key mechanisms used by the Chinese Government to ensure a continued supply of resources to fuel the growing Chinese economy [22]. For that reason, we expect that African countries resource endowment will be positively related to Chinese ODI. We use the mean ratio of ore and metal exports to control for resource seeking FDI. The data is obtained from the World Bank Development Indicators database.

\subsubsection{Control Variables}

We also include several control variables into our model.

First, we control for the impact of inflation. We expect Chinese ODI to decrease when the African host country experiences currency inflation, because high inflation often means a rise in local input prices and a devaluation of the Multinational firm's profits. We collect the data on inflation from the IMF's World Economic Outlook.

We also consider the effects of exchange rates. Just as an undervalued home currency encourages exports over FDI, we expect Chinese FDI to increase when the African host country's currency is depreciated vis-à-vis China's currency [23]. Thus, we include a variable reflecting the exchange rate in the surveyed period. The data is collected from the World Bank Development Indicators Database.

We include a control variable reflecting the degree of openness of the host African country. Although empirical tests revealed mixed results, most studies agree that the more a country is open to international trade, the more other countries are willing to invest there because "most investment projects are directed towards the tradable sector" [21]. Thus, we believe that African countries' Openness is positively related to Chinese FDI. Openness is usually measured by the ratio of exports plus imports to GDP.

We then control for geographic distance because according to the theory of Internationalization, we expect that market-seeking companies would prefer trade over FDI for countries that are geographically close, and FDI over trade for country that are far away. However, since geographical distance is also expected to increase transportation costs, it can also hinder FDI. Thus, we expect a negative relation between Geographical distance and Chinese ODI in African coun- 
tries. We collect the data between China and African countries from Google Maps.

Finally, we control for export flows from China to each of the host African countries. Many times, multinationals start by doing trade before investing in the host country. Their trade activities enable them to obtain information and to get familiar with local services such as transportation and financial services [22]. Thus, we expect Chinese exports to be positively related to Chinese ODI. Data is collected from the UN COMTRADE database.

Our variables, their expected signs and their respective data source are detailed in the Appendix 2.

\subsection{Methodology}

Following previous studies, we use ordinary least squares regression analyses to test our hypothesis regarding the impact of cultural distance and on Chinese Outward FDI in African countries [4] [24]. We assume the error structure as heteroscedastic and uncorrelated.

The Model

We test our hypothesis using the following log-linear model:

$$
\begin{aligned}
\ln F D I_{i j t}= & \beta_{0}+\beta_{1} \ln C D I S T_{i j}+\beta_{2} \ln G D P_{j t}+\beta_{3} \ln G D P C_{j t}+\beta_{4} \ln O R E_{j t} \\
& +\beta_{5} \ln I N F_{j t}+\beta_{6} \ln X R T_{i j t}+\beta_{7} \ln O P E N_{j t}+\beta_{8} \ln G D S I T_{j t} \\
& +\beta_{9} \ln E X P_{i j t}+\varepsilon_{i j t}
\end{aligned}
$$

\section{Estimation Results and Discussion}

Table (1) presents the results of estimations on the impact of the variable "cultural distance" on China's foreign direct investment into African countries. Our main explaining variable "cultural distance" is correctly signed and significant. African countries GDP, GDP per capita, natural resources endowment, and China's exports to African countries variables are correctly signed and significant. Inflation is significant but incorrectly signed. Geodesic distance and trade openness are incorrectly signed and insignificant.

Table (2) presents the results of estimations on the impact of the cultural dimension "Power Distance" on China's foreign direct investment into African countries. Our main explaining variable, the cultural dimension "power distance", is incorrectly signed and insignificant. African country's GDP per capita, natural resources endowments, exchange rate, and Exports are correctly signed and insignificant. GDP, Openness, and Geodesic Distance are incorrectly signed and insignificant. The variable Inflation is significant, but incorrectly signed.

Table (3) presents the results of estimations on the impact of the cultural dimension "Individualism vs Collectivism" on China's foreign direct investment into African countries. Our main explaining variable, the cultural dimension "Individualism vs Collectivism", is incorrectly signed and insignificant. African countries GDP, GDP per capita, natural resources endowment, Exchange rates, 
and China's exports to African countries variables are correctly signed and significant. Geodesic Distance and inflation are significant, but incorrectly signed. Openness is insignificant and incorrectly signed.

Table (4) presents the results of estimations on the impact of the cultural dimension "Masculinity vs Femininity" on China's foreign direct investment into African countries. Our main explaining variable, the cultural dimension "Masculinity vs Femininity", is correctly signed and significant. African countries GDP, GDP per capita, natural resources endowment, Exchange rates, and China's exports to African countries variables are correctly signed and significant. Inflation is significant, but incorrectly signed. Geodesic distance and trade openness are incorrectly signed and insignificant.

Table (5) presents the results of estimations on the impact of the cultural dimension "Uncertainty Avoidance" on China's foreign direct investment into African countries. Our main explaining variable, the cultural dimension "Uncertainty Avoidance”, is correctly signed and significant. GDP per capita, natural resources endowment, Exchange rates, and China's exports to African countries variables are correctly signed and significant. Inflation is significant, but incorrectly signed. Geodesic Distance is correctly signed but insignificant. Trade openness is incorrectly signed and insignificant.

We can summarize our results the following way: Figure 2.

1) China's FDI in Africa is positively related to the host country's GDP per capita, the host country's natural resource endowment, and China's exports to that country.

These results of China's do not differ from the conventional of FDI theory. The main motivations of Chinese multinationals investing in Africa are to seek new markets and resources. Also, Chinese enterprises generally enter the African market through trade (exports).

These results are probably related to the study period (2003-2015). After year

\begin{tabular}{|c|c|c|c|c|c|c|c|c|c|}
\hline \multicolumn{2}{|c|}{ (1) } & \multicolumn{2}{|c|}{ (2) } & \multicolumn{2}{|c|}{ (3) } & \multicolumn{2}{|c|}{ (4) } & \multicolumn{2}{|c|}{ (5) } \\
\hline \multirow[t]{2}{*}{ logcdist } & $-0.703^{* * *}$ & logpowerdist & 0.250 & logindcollect & 0.120 & logmascfem & $-0.147 * * *$ & loguncertavoid & $-0.533^{* * *}$ \\
\hline & $(0.243)$ & & $(0.181)$ & & $(0.0878)$ & & $(0.0510)$ & & $(0.181)$ \\
\hline \multirow[t]{2}{*}{ loggdp2 } & $0.342 * *$ & loggdp2 & 0.255 & loggdp2 & $0.422 * * *$ & loggdp2 & $0.367 * * *$ & loggdp2 & $0.296 * *$ \\
\hline & $(0.141)$ & & $(0.172)$ & & $(0.160)$ & & $(0.142)$ & & $(0.141)$ \\
\hline \multirow[t]{2}{*}{ loggdppc2 } & $0.586 * * *$ & loggdppc2 & $0.746^{* * *}$ & loggdppc2 & $0.571^{* * *}$ & loggdppc2 & $0.545^{* * *}$ & loggdppc2 & $0.619 * * *$ \\
\hline & $(0.137)$ & & $(0.156)$ & & (0.165) & & $(0.137)$ & & (0.138) \\
\hline \multirow[t]{2}{*}{ logore } & $0.154^{* * *}$ & logore & $0.239 * * *$ & logore & $0.181^{* * *}$ & logore & $0.156^{* * *}$ & logore & $0.130 * * *$ \\
\hline & $(0.0441)$ & & $(0.0561)$ & & $(0.0471)$ & & $(0.0442)$ & & $(0.0427)$ \\
\hline \multirow[t]{2}{*}{ loginflation } & $0.222^{* * *}$ & loginflation & $0.325^{* * *}$ & loginflation & $0.258 * * *$ & loginflation & $0.223^{* * *}$ & loginflation & $0.200^{* *}$ \\
\hline & (0.0833) & & $(0.0974)$ & & $(0.0843)$ & & $(0.0833)$ & & $(0.0845)$ \\
\hline \multirow[t]{2}{*}{ logxrates } & 0.0811 & logxrates & $0.246^{* * *}$ & logxrates & $0.173^{* * *}$ & logxrates & $0.113^{* *}$ & logxrates & $0.0930 *$ \\
\hline & $(0.0564)$ & & $(0.0660)$ & & $(0.0594)$ & & $(0.0521)$ & & $(0.0530)$ \\
\hline \multirow[t]{2}{*}{ logopenness } & -0.000798 & logopenness & 0.416 & logopenness & -0.221 & logopenness & -0.211 & logopenness & -0.131 \\
\hline & $(0.364)$ & & $(0.433)$ & & $(0.402)$ & & $(0.361)$ & & $(0.361)$ \\
\hline \multirow[t]{2}{*}{ loggeodist } & -0.218 & loggeodist & -0.846 & loggeodist & $1.524^{*}$ & loggeodist & 0.934 & loggeodist & -0.462 \\
\hline & $(0.741)$ & & $(0.942)$ & & $(0.875)$ & & $(0.857)$ & & (0.739) \\
\hline \multirow[t]{2}{*}{ logexports } & $0.433^{* * *}$ & logexports & $0.358^{* * *}$ & logexports & $0.327 * * *$ & logexports & $0.411^{* * *}$ & logexports & $0.458 * * *$ \\
\hline & $(0.0885)$ & & $(0.0971)$ & & $(0.0914)$ & & $(0.0881)$ & & $(0.0892)$ \\
\hline \multirow[t]{2}{*}{ Constant } & 4.733 & Constant & 7.214 & Constant & -9.831 & Constant & -5.496 & Constant & 7.217 \\
\hline & (6.592) & & (8.361) & & (7.464) & & (7.682) & & (6.566) \\
\hline Observations & 265 & Observations & 204 & Observations & 230 & Observations & 265 & Observations & 265 \\
\hline
\end{tabular}

Figure 2. Correlation matrix. 
2000, China's foreign direct investment began to diversify. Chinese state-owned enterprises, mainly resource-seeking continued to invest, but private-owned enterprises that are mostly market-seeking have started to take the leading role on the African market.

2) Cultural distance has a significant negative impact on Chinese investment in Africa. Furthermore, distance in two of the four cultural dimensions has a bigger impact on FDI: Masculinity/Femininity and Uncertainty avoidance.

These results show that cultural distance does affect Chinese companies' decision to invest. However, only certain aspects of China-Africa cultural distance have a negative impact on China's foreign direct investment. Therefore, it is necessary to make further research on the impact mechanism of cultural distance on Chinese FDI in Africa.

\section{Conclusions}

Since the establishment of the Forum on China-Africa Cooperation back in 2000, Chinese investment in Africa rapidly increased. Almost two decades later, the economic partnership between China and African countries is facing both opportunities and challenges. Chinese investment in Africa and the impact of Cultural distance are two hot topics in the literature. However, few papers have studied the impact of cultural distance on Chinese investment in Africa. We believe that a good understanding of the impact of cultural distance is one of the key factors that will determine the future of the economic relationship between China and African countries.

We employ generalized least squares regression analyses to test our hypothesis regarding the impact of cultural distance and on Chinese Outward FDI in 40 African countries from 2003 to 2015. Our results indicate that cultural distance has a significant negative impact on Chinese investment in Africa. Furthermore, distance in two of the four cultural dimensions has a bigger impact on FDI: Masculinity/Femininity and Uncertainty Avoidance. We conclude that from China-Africa perspective, cultural distance creates additional barriers to Chinese investment.

This study faces multiple statistical limitations that affect the robustness of the results, calling for more efforts to study empirically the impact of cultural distance on Chinese investment in Africa. Nonetheless, the conclusions of this paper show that the impact of cultural distance is real. We also find that while some aspects of the cultural distance have a negative impact on Chinese FDI, some other aspects of culture don't. Thus, more research efforts are also required to determine how cultural distance negatively affects Chinese FDI, in order to find the appropriate solutions to the cultural conflicts that often involve Chinese companies in Africa. Also, because African countries are different, each country's policies towards China are also very different. Therefore, the impact of cultural distance may vary from country to another. Future research should focus on the impact of cultural distance on the Chinese investments in individual 
African countries.

\section{References}

[1] Tadesse, B., White, R. and Huang, Z. (2017) Does China's Trade Defy Cultural barriers? International Review of Applied Economics, 31, 398-428. https://doi.org/10.1080/02692171.2016.1257583

[2] Hofstede, G. (2001) Culture's Consequences: Comparing Values, Behaviors, Institutions and Organizations across Nations. Sage, Thousand Oaks, CA.

[3] Kaplinsky, R. and Morris, M. (2009) Chinese FDI in Sub-Saharan Africa: Engaging with Large Dragons. European Journal of Development Research, 21, 551-569. https://doi.org/10.1057/ejdr.2009.24

[4] Buckley, P., Clegg, J., Liu, X., Voss, H. and Zheng, P. (2007) The Determinants of Chinese Outward Foreign Direct Investment. Journal of International Business Studies, 38, 499-451. https://doi.org/10.1057/palgrave.jibs.8400277

[5] Cheung, Y.W., De Haan, J., Qian, X. and Yu, S. (2010) China's Outward Direct Investment in Africa. Review of International Economics, Wiley Blackwell, 20, 201-220.

[6] Dunning, J.H. (2006) Comment on Dragon Multinationals: New Players in the 21st Century Globalization. Asia Pacific Journal of Management, 23, 139-141. https://doi.org/10.1007/s10490-006-7161-1

[7] Johanson, J. and Vahlne, J. (1977) The Internationalization Process of the Firm: A Model of Knowledge Development and Increasing Foreign Market Commitments. Journal of International Business Studies, 8, 23-32. https://doi.org/10.1057/palgrave.jibs.8490676

[8] Qi, J., Zhao, Y. and Zhang, Z. (2015) An Empirical Study of the Impacts of Geographic and Cultural Distance on Chinese ODI. Edith Cowan University, Perth.

[9] Siegel, J., Licht, A. and Schwartz, S. (2013) Egalitarianism, Cultural Distance, and FDI: A New Approach. Organization Science, 24, 1-21. https://doi.org/10.1287/orsc.1120.0776

[10] Kogut, B. and Singh, H. (1988) The Effect of National Culture on the Choice of Entry Mode. Journal of International Business Studies, 19, 411-432. https://doi.org/10.1057/palgrave.jibs.8490394

[11] Barkema, H., Bell, J. and Pennings, J. (1996) Foreign Entry, Cultural Barriers, and Learning. Strategic Management Journal, 17, 151-166. https://doi.org/10.1002/(SICI)1097-0266(199602)17:2<151::AID-SMJ799>3.0.CO;2$\underline{Z}$

[12] Korneliussen, T. and Blasius, J. (2008) The Effects of Cultural Distance, Free Trade Agreements, and Protectionism on Perceived Export Barriers. Journal of Global Marketing, 21, 217-229. https://doi.org/10.1080/08911760802152074

[13] Vermeulen, F. and Barkema, H. (2001) Learning through Acquisitions. Academy of Management Journal, 44, 457-76. https://doi.org/10.2307/3069364

[14] Loree, D. and Guisinger, S. (1995) Policy and Non-Policy Determinants of U.S. Equity Foreign Direct Investment. Journal of International Business Studies, 26, 281-299. https://doi.org/10.1057/palgrave.jibs.8490174

[15] Sethi, D., Guisinger, S., Phelan, S. and Berg, D. (2003) Trends in Foreign Direct Investment Flows: A Theoretical and Empirical Analysis. Journal of International Business Studies, 34, 315-326. https://doi.org/10.1057/palgrave.jibs.8400034

[16] Tang, L. (2012) The Direction of Cultural Distance on FDI: Attractiveness or In- 
congruity? Cross Cultural Management. An International Journal, 19, 233-256. https://doi.org/10.1108/13527601211219919

[17] Zhang, J. and Daly, K. (2011) The Determinants of China's Outward Foreign Direct Investment. Emerging Markets Review, 1, 389-398.

https://doi.org/10.1016/j.ememar.2011.06.001

[18] Tong, S. (2003) Ethnic Chinese Networking in Cross-Border Investment: The Impact of Economic and Institutional Development. University of Hong Kong, Hong Kong Institute of Economics and Business Strategy, Hong Kong.

[19] Erdener, C. and Shapiro, D. (2005) The Internationalization of Chinese Family Enterprises and Dunning's Eclectic MNE Paradigm. Management and Organization Review, 1, 411-436. https://doi.org/10.1111/j.1740-8784.2005.00021.x

[20] Quer, D., Claver, E. and Rienda, L. (2012) Political Risk, Cultural Distance, and Outward Foreign Direct Investment: Empirical Evidence from Large Chinese Firms. Asia Pacific Journal of Management, 29, 1089-1104. https://doi.org/10.1007/s10490-011-9247-7

[21] Chakrabarti, A. (2001) The Determinants of Foreign Direct Investment: Sensitivity Analysis of Cross-Country Regressions. Kyklos, 54, 89-114. https://doi.org/10.1111/1467-6435.00142

[22] Zhan, J. (1995) Transnationalization and Outward Investment: The Case of Chinese Firms. Transnational Corporations, 4, 67-100.

[23] Clegg, L. and Scott-Green, S. (1999) The Determinants of New FDI Capital Flows into the EC: A Statistical Comparison of the USA and Japan. Journal of Common Market Studies, 37, 597-616. https://doi.org/10.1111/1468-5965.00198

[24] Blomkvist, K. and Drogendijk, R. (2013) The Impact of Psychic Distance on Chinese outward Foreign Direct Investments. Management International Review, 53, 659-686. https://doi.org/10.1007/s11575-012-0147-y 


\section{Appendix 1}

Selected African Countries and Their Cultural Distance with China.

Source: Author's calculation. Data from Hofstede's National Culture database.

\begin{tabular}{|c|c|c|c|c|c|}
\hline African Country & Power distance & Individualism vs collectivism & Masculinity vs Feminity & Uncertainty avoidance & Cultural Distance \\
\hline Angola & 0.252318309 & 0.051561725 & 14.94519425 & 14.24512987 & 7.37355104 \\
\hline Benin & 2.803536769 & 0.322260783 & 1.808114239 & 9.892451299 & 3.706590773 \\
\hline Burkina Faso & 2.803536769 & 0.322260783 & 1.808114239 & 9.892451299 & 3.706590773 \\
\hline Burundi & 2.803536769 & 0.322260783 & 0.254266065 & 6.331168831 & 2.427808112 \\
\hline Cabo Verde & 0.700884192 & 0 & 18.37072318 & 1.582792208 & 5.163599896 \\
\hline Cameroon & 0 & 1.289043133 & 0.254266065 & 9.892451299 & 2.858940124 \\
\hline Central African Republic & 2.803536769 & 0.322260783 & 1.808114239 & 9.892451299 & 3.706590773 \\
\hline Chad & 0 & 4.176499752 & 1.384337464 & 22.85551948 & 7.104089174 \\
\hline Congo, Dem. Rep. of the & 2.803536769 & 0.322260783 & 1.808114239 & 9.892451299 & 3.706590773 \\
\hline Congo, Republic of & 2.803536769 & 0.322260783 & 1.808114239 & 9.892451299 & 3.706590773 \\
\hline Côte d'Ivoire & 2.803536769 & 0.322260783 & 1.808114239 & 9.892451299 & 3.706590773 \\
\hline Djibouti & 2.803536769 & 0 & 0.007062946 & 9.892451299 & 3.175762754 \\
\hline Egypt & 2.803536769 & 0.322260783 & 3.114759294 & 39.56980519 & 11.45259051 \\
\hline Equatorial Guinea & 0 & 1.289043133 & 0.254266065 & 9.892451299 & 2.858940124 \\
\hline Ethiopia & 2.803536769 & 0 & 0.007062946 & 9.892451299 & 3.175762754 \\
\hline Gabon & 2.803536769 & 0.322260783 & 1.808114239 & 9.892451299 & 3.706590773 \\
\hline Ghana & 0 & 0.322260783 & 4.774551661 & 19.38920455 & 6.121504248 \\
\hline Guinea & 2.803536769 & 0.322260783 & 3.114759294 & 9.892451299 & 4.033252036 \\
\hline Guinea-Bissau & 0.252318309 & 0.051561725 & 14.94519425 & 14.24512987 & 7.37355104 \\
\hline Kenya & 2.803536769 & 0.322260783 & 0.254266065 & 6.331168831 & 2.427808112 \\
\hline Liberia & 2.803536769 & 0 & 4.774551661 & 6.331168831 & 3.477314316 \\
\hline Libya & 0 & 4.176499752 & 1.384337464 & 22.85551948 & 7.104089174 \\
\hline Madagascar & 2.803536769 & 0 & 0.007062946 & 9.892451299 & 3.175762754 \\
\hline Malawi & 2.803536769 & 1.289043133 & 4.774551661 & 6.331168831 & 3.799575099 \\
\hline Mali & 0 & 4.176499752 & 1.384337464 & 22.85551948 & 7.104089174 \\
\hline Mauritania & 0 & 4.176499752 & 1.384337464 & 22.85551948 & 7.104089174 \\
\hline Mauritius & 2.803536769 & 0 & 0.007062946 & 9.892451299 & 3.175762754 \\
\hline Morocco & 2.803536769 & 8.713931582 & 1.193637915 & 22.85551948 & 8.891656437 \\
\hline Mozambique & 0.700884192 & 0.322260783 & 5.537349856 & 3.102272727 & 2.41569189 \\
\hline Niger & 0 & 4.176499752 & 1.384337464 & 22.85551948 & 7.104089174 \\
\hline Nigeria & 0 & 1.289043133 & 0.254266065 & 9.892451299 & 2.858940124 \\
\hline Rwanda & 2.803536769 & 0.322260783 & 0.254266065 & 6.331168831 & 2.427808112 \\
\hline Senegal & 2.803536769 & 0.322260783 & 3.114759294 & 9.892451299 & 4.033252036 \\
\hline Sierra Leone & 2.803536769 & 0 & 4.774551661 & 6.331168831 & 3.477314316 \\
\hline \begin{tabular}{|l|} 
Sudan \\
\end{tabular} & 0 & 4.176499752 & 1.384337464 & 22.85551948 & 7.104089174 \\
\hline Tanzania & 2.803536769 & 0.322260783 & 4.774551661 & 6.331168831 & 3.557879511 \\
\hline Togo & 2.803536769 & 0.322260783 & 1.808114239 & 9.892451299 & 3.706590773 \\
\hline Uganda & 2.803536769 & 0.322260783 & 0.254266065 & 6.331168831 & 2.427808112 \\
\hline Zambia & 11.21414708 & 2.90034705 & 4.774551661 & 6.331168831 & 6.305053655 \\
\hline Zimbabwe & 11.21414708 & 2.90034705 & 4.774551661 & 6.331168831 & 6.305053655 \\
\hline
\end{tabular}




\section{Appendix 2}

The model variables, their expected signs and their respective data source.

\begin{tabular}{|l|c|c|c|}
\hline \multicolumn{1}{|c|}{ Variable } & Description & Expected Sign & \multicolumn{1}{c|}{ Data source } \\
\hline cdist & Cultural Distance between China and African countries & $(-)$ & Hofstede's national culture database \\
\hline gdp2 & African countries' GDP & $(+)$ & World Bank Development Indicators database \\
\hline gdppc2 & African countries' GDP per capita & $(+)$ & World Bank Development Indicators database \\
\hline ore & African countries' ration of ore and metal exports & $(+)$ & World Bank Development Indicators database \\
\hline inflation & Inflation of African countries' currency & $(-)$ & IMF Database \\
\hline xrate & Echange rate between China's currency and the African country's currency & $(+)$ & IMF Database \\
\hline openness & African countries' openness to trade & $(+)$ & World Bank Development Indicators database \\
\hline geodist & Geodesic distance between China and African countries & $(-)$ & CEPII Database \\
\hline exports & China's exports to African countries & $(+)$ & UN COMTRADE database \\
\hline
\end{tabular}

